\title{
機械式円振動付与スピンドルを用いた振動外周刃切断方式の加工特性に関する研究 Studies on Vibratory OD-Blade Slicing Characteristics using Mechanical Circular Vibration Spindle
}

\author{
正 畧田 道雄（金沢工大） ○学 塚田 広昌（金沢工大院） \\ 正 石川 憲一（金沢工大）正 諏訪部 仁（金沢工大）
}

Michio UNEDA, Kanazawa Institute of Technology, 7-1, Ohgigaoka, Nonoichi, Ishikawa, 921-8501, Japan

Hiromasa TSUKADA, Graduate school of Kanazawa Institute of Technology

Ken-ichi ISHIKAWA, Kanazawa Institute of Technology

Hitoshi SUWABE, Kanazawa Institute of Technology

Key Words: Brittle Materials, OD-Blade, Vibratory Slicing

\section{1. 緒 言}

セラミックスをはじめとした硬脆材料の切断加工技術に おいて, 加工原理や装置が簡便であるという理由から, 外周 刃を用いた切断方式が一般的に用いられている. 特に, 現在 においては切断長さがメートル単位長となる液晶ガラスな どに対する高効率・高精度切断技術が必要とされている ${ }^{1)}$. 外周刃方式の特徵として, 薄刃を用いる加工であることから カーフロスが少ないことを利点とする反面, 横剛性の低さに よって, 加工中に弾性変形を生じて加工精度や工具寿命が低 下するという久点がある. しかしながら，材料のスループッ 卜を向上させる観点から, より薄刃の外周刃を使用する必要 があり, 外周刃の弾性変形による切断効率・精度の低下を抑 制することが課題である.

上記のような背景から, 図 1 に示すような振動外周刃切断 方式が，著者らによってこれまで検討されてきている ${ }^{2) 31}$. 本方式は, 外周內側あるいは工作物側に振動を付与すること によって外周刃の弾性変形を抑制するとともに, 切断抵抗が 減少するという利点を有している. それに伴って, 加工精度 が向上するのみならず, 工具寿命が延長するといった顕著な 効果も得られることが明らかにされている. 本報告では，工 作物の大きさに制約を受けず，理論的に最も効果が高い3)外 周刃側に円振動を付与した場合について実験的に検討した 結果について述べる.

\section{2. 振動切断における切断抵抗}

無振動切断並びに, 鉛直方向振動や円振動を用いた各々の 振動切断においては，八角リング式動力計を用いて切断抵抗 を計測した. 切断抵抗は, 外周刃と工作物が接触する面積が 最大となる範囲で得られる切断抵抗の平均值として定義す る. 主な実験条件を表 1 に示すとともに，実験結果を図 2 に 示す.この結果から, 切断送り速度の増加に伴って切断抵抗 が直線的に増加し, 無振動切断に対して, 円振動及び鉛直方 向振動を付与した場合には，切断抵抗が減少することが分か る.

振動切断における切断抵抗の減少効果は, 無振動切断での 工具と工作物間の接触による抵抗を接触抵抗 $F_{c}$ として定義 することで説明できる. 振動切断の場合, 外周刃と工作物は 接触と分離を繰り返す。この接触, 分離の割合を与えるパラ メータである接触率 $\eta(\dot{X})$ が接触抵抗 $F_{c}$ に関係するため, 振 動切断における平均切断抵抗 $\bar{F}_{n v}(\dot{X})$ は切断送り速度を $\dot{X}$, 増 加率を $\varphi$ とすると次のように表される.

$$
\overline{F_{n v}}(\dot{X})=\varphi \cdot \dot{X}+F_{c} \cdot \eta(\dot{X})
$$

この式から, 振動切断を行うことによって, 接触率 $\eta(\dot{X})$ の 減少に伴って接触抵抗が減少し, 平均切断抵抗 $\overline{F_{n v}}(\dot{X})$ が減少 したと考えられる. また, 実験結果から, 円振動に対して鉛直方 向振動の切断抵抗が若干減少している.このことは図 2 の実験
条件下においては, 図 3 で示したように円振動の振幅が $100 \mu \mathrm{m}$ の場合に接触率が $11.5 \%$ であるのに対し, 鉛直方向振動の振幅 が $170 \mu \mathrm{m}$ の場合に 9.15\%であることが原因と考えられる. 図 3 に 示す振動振幅と接触率の関係から, 円振動と鉛直方向振動の場 合, ほとんど同様な傾向を示し, 振幅の増加に伴って接触率が 減少する.すなわち, 図 2 の結果においては, 振幅が大きく, 接 触率の小さい鉛直方向振動の場合の方が, 円振動の場合と比

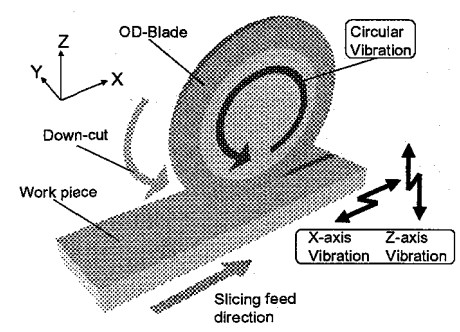

Fig.1 Schematic illustration of vibratory OD-Blade slicing

Table1 Main experimental conditions

\begin{tabular}{|c|c|}
\hline OD-Blade size & $\phi 125 \times 1 \mathrm{~mm}^{\mathrm{t}}$ \\
\hline Slicing depth & $4 \mathrm{~mm}$ \\
\hline Applied frequency & $0,10 \mathrm{~Hz}$ \\
\hline Workpiece & Soda glass, $50 \times 60 \times 5$ \\
\hline Slicing feed velocity & $18,42,60,78,102,120 \mathrm{~mm} / \mathrm{min}$ \\
\hline Applied amplitude & Circular viblation: $100 \mu \mathrm{m}, Z$-axis viblation: $170 \mu \mathrm{m}$ \\
\hline Number of OD-blade rotation & $5000 \mathrm{rpm}$ \\
\hline Slicing system & Down-cut \\
\hline
\end{tabular}

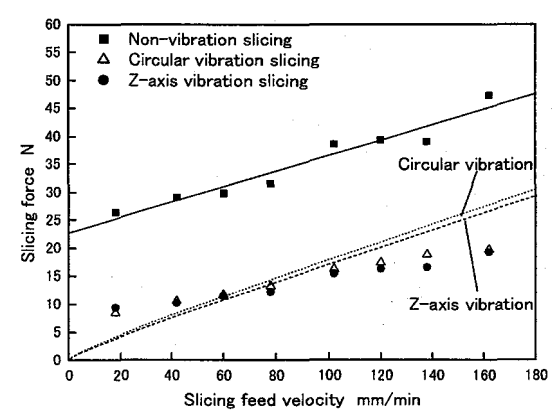

Fig.2 Relationship between slicing force and slicing feed velocity

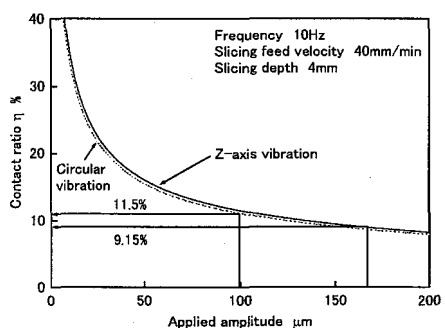

Fig.3 Relationship between contact ratio and applied vibration amplitude 
較して切断抵抗が僅かに減少したと考えられる.

一方, 本実験において, 接触率は切断送り速度をパラメータと したものである. そこで, 図 2 中に接触率と切断送り速度の関係 から求めた振動切断における平均切断抵抗の理論曲線を点線 で示した.この結果から, 振動切断の切断抵抗 (実験值) は, 理 論曲線に対して, ある程度の傾向の一致が見られるが, 傾きに差 が生じていることが分かる.この原因として, 振動切断の理論曲 線は, 無振動切断の近似曲線を基に導いているが, 外周刃の弾 性変形が及ぼす影響については考慮していないことが原因と考 えられる. すなわち, 無振動切断において, 外周刃の弾性変形 によって切断抵抗が増加したため, 振動切断の理論曲線に影響 を及ぼしたと考えられる.しかし，外周刃切断方式の一般的な切 断送り速度として用いられる $60 \mathrm{~mm} / \mathrm{min}$ 付近では, 理論と一致し ているため, 本理論解析手法は有効であると考えられる.

\section{3. 振動切断における切断面のうねり形状の変化}

振動切断における切断面うねりについて実験的に検討し た. 測定には切断片を作成し，触針式表面形状測定器（株式 会社東京精密製)を用いて图 4 に示すような方法で測定した.

图 5(a)に無振動切断における切断面うねり，図 5(b)に振動

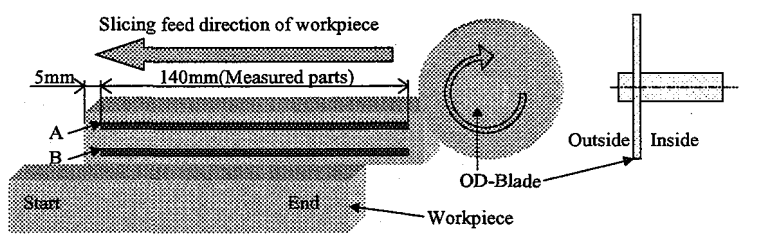

Fig.4 Illustration of measurement method of waviness of sliced surface

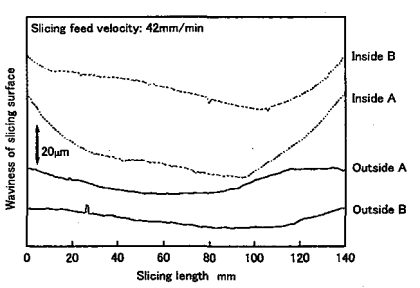

(a) Non-vibration slicing

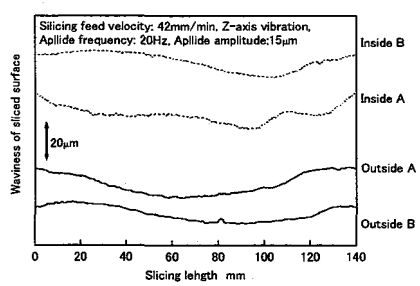

(b) Vibration slicing
Fig.5 Waviness profiles of sliced surface

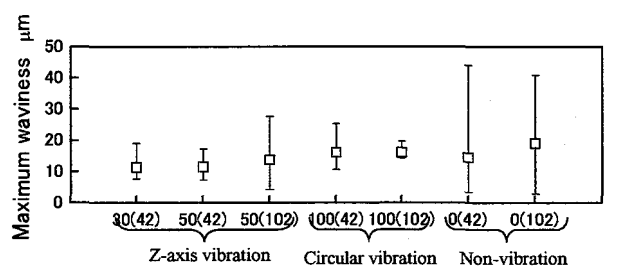

Apllide amplitude $\mu \mathrm{m}$ (Slicing feed velocity $\mathrm{mm} / \mathrm{min}$ )

Fig.6 Dispersion of maximum waviness of sliced surface

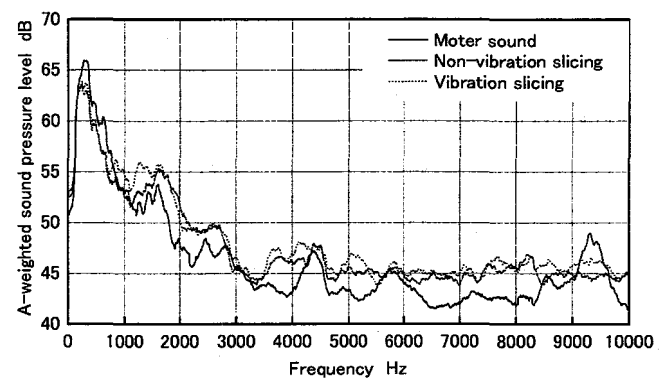

Fig.7 Sound spectrum
切断における切断面うねりの測定結果を示す.これらの結果 から, 切断面のうねり形状は, 無振動切断, 振動切断の双方 が途中で湾曲している。これは外周刃が工作物に接触した場 合に弾性変形を生じ, その状態を保持したまま加工が進行す ることによって, 切断送り方向に対して切断溝方向が傾斜し たことに起因するものと考えられる.さらに，切断終了付近 で外周刃が工作物から離れる過程において弾性変形が元に 戻ることによって湾曲した形状になったと考えられる.また， 無振動切断と比較して振動切断の場合に切断面うねりが減 少していることがわかる. 振動切断において，これまでの理 論的・実験的検討から, 外周刃と工作物が接触と分離を繰り 返すことによって, 外周刃の弾性変形が抑制される（原点復 帰効果 ${ }^{4)}$ ) ことがわかっている. つまり，外周刃に振動を付 与したことによって弾性変形が抑制され，切断面うねりが減 少したものと考えられる. 次に, 図 6 に 1 回の切断で作成さ れる切断面うねりの最大值を切断面最大うねりとし, その平 均值とバラツキを示した.この結果から振動切断は, 無振動 切断と比較して切断面うねりの最大值のバラツキが小さい ことが分かる. すなわち, 振動切断によって, 無振動切断と 比較して切断面の形状が安定すると考えられる.

\section{4. 切断騒音の評価}

外周刃切断を行う場合，高速で回転する外周刃や，加工部 から発せられる騒音は, 作業環境の悪化をもたらす.そこで, 無振動切断, 並びに振動切断の加工中の騒音を定量化するこ とによって, 振動付与の効果を検証した. 実験は, 普通騒音 計を外周刃側面に向けて設置して行った。これを用いて，実 験装置から発生した騒音を $\mathrm{A}$ 特性音圧レベル $L_{p A}$ として測定 した. 図 7 に，モータ音，無振動切断中の騒音，振動切断中 の騒音について, FFT 解析した A 特性音圧レベル $L_{p A}$ を示す. この結果から, 無振動切断と振動切断の $L_{p A}$ を比較した場合, ほとんど波形が一致していることが分かる．また，無振動切 断, 並びに振動切断の $L_{p A}$ とモータ音の $L_{p A}$ を比較した場合, $4000 \mathrm{~Hz}$ から $8000 \mathrm{~Hz}$ の範囲においてモータ音の $L_{p A}$ が減少し ていることが分かる.これらのことから，切断によって発生 する騒音は $4000 \mathrm{~Hz}$ から $8000 \mathrm{~Hz}$ の範囲に存在し, 振動切断 の騒音は無振動切断と変わらないレベルであることから,た とえ振動切断を行ったとしても外周刃や加工部から発生す る騒音が作業環境に及ぼす影響は無いと考えられる. 加えて 騒音スペクトルが同一であることから，無振動切断と振動切 断で加工機構は変わらないと考えられる.

\section{5. 結 言}

本論文で得られた結果を以下に要約する。

（1） 円振動を用いた振動切断においても，切断抵抗が減少す ることを実験的に確認した。

(2) 振動切断を用いることによって，切断面うねりを減少さ せる効果がある。

(3) 振動切断加工中の騒音は無振動切断と同等である.

参考文献

1) 三井鉣山マテリアル株式会社:MATERIALS, (2004).

2) 石川憲一, 諏訪部 仁, 栘田一也, 畧田道雄: 振動を利用した外周刃切断の加 工特性に関する研究, 精密工学会誌, 62, 3 (1996) 438 .

3) 石川憲一, 諏訪部 仁, 敨田道雄: 振動外周刃スライシング方式に関する研究一 切断抵抗に及ぼす加振系の影響一, 砥粒加工学会誌, 44, 5 (2000) 224.

4) 畧田道雄, 石川憲一, 諏訪部仁: 振動外周刃スライシング方式におけるブレード の原点復帰効果に関する実験的研究, 精密工学会誌, 66, 7 (2000) 1115.

5) 畧田道雄, 塚田広昌, 石川憲一, 諏訪部仁:機械式円振動スピンドルを用いた 振動外周刃切断方式の基本加工特性評価に関する研究, 2005 年度砥粒加工 学会学術講演会講演論文集, (2005). 